\title{
Functional properties of maize flour (Zea mays) and stability of its paste (tuwo) as influenced by processing methods and baobab (Adansonia digitata) pulp inclusion
}

\section{Olajide Emmanuel Adedeji, Nsakpuma Tadawus}

\author{
Federal University Wukari, Wukari, Nigeria
}

Keywords:

Baobab pulp

Grit soaking

Maize

Flour

Syneresis

Tuwo

Article history:

Received 12.03.2019

Received in revised form 18.05.2019

Accepted 30.05.2019

Corresponding

author:

Olajide Emmanuel

Adedeji

E-mail:

jdadedeji@gmail.com

DOI: $10.24263 / 2310-$

1008-2019-7-1-7

\section{Abstract}

Introduction. Tuwo, a gel-like dumpling produced by heating maize flour slurry to obtain a smooth dough, is the most important staple food in Northern Nigeria.

Materials and methods. Maize flours (MF) were obtained using "grit non-soaking (GNS)" and "grit soaking (GSM)" methods. Baobab pulp (BPF) at 0, 5 and 10\% w/w was incorporated into the MF and tuwo was prepared from the blends. Functional and colour order properties of MF, stability and sensory properties of tuwo were determined using standard methods.

Results and discussion. Swelling capacity, water absorption capacity, dispersibility, paste clarity and least gelation of blends were $5.44-5.85 \mathrm{~mL} / \mathrm{g}, 2.19-2.49 \mathrm{~mL} / \mathrm{g}$, $50.53-61.66 \%, 1.86-4.50 \%$ and $2-6 \%$, respectively. Flour produced by GNS method and containing $10 \%$ BPF had highest loose bulk density $(0.53 \mathrm{~g} / \mathrm{mL})$, packed bulk density $(0.77 \mathrm{~g} / \mathrm{mL})$ and swelling capacity $(5.85 \%)$. Peak, breakdown and final viscosity of blends were 473.83-792.63 RVU, 391.17-626.33 RVU and 578.42-905.00 RVU, respectively. $\mathrm{L}^{*}, \mathrm{a}^{*}, \mathrm{~b}^{*}$, hue angle, chroma and colour intensity of blends were $75.30-85,97,-0.30-1.26,9.14-$ 14.94, 59.33-88.20, 5.67-11.58 and 10.10-20.39, respectively. There was no significant $(\mathrm{p}>0.05)$ difference between $100 \%$ MF produced by GNS and GSM (control samples) and blends of MF and BPF in terms of swallowability and mouldability while significantly $(p<0.05)$ higher scores were recorded for the control samples in colour, taste, flavour and general acceptability. At the end of the first day of ambient storage, syneresis was 5.6-16.3\% and $2.5-10.2 \%$ for tuwo produced by GNS and GSM, respectively. Syneresis was $2.5-14.9 \%$ and $1.8-2.2 \%$ for tuwo produced by GNS and GSM respectively under refrigeration storage condition.

Conclusion. This study showed improvement in the quality of maize flour and stability of tuwo as a result of baobab pulp inclusion. 


\section{Introduction}

Maize (Zea mays) is a popular crop worldwide due to its functionality as a food source for both human and animals [1]. It is a dietary staple for a teeming world population of 400 million who are majorly in Africa and Central America [2]. Maize contains essential nutrients such as carbohydrate and dietary fiber which provide adequate calorie required by the body [1]. Earlier reports showed that maize contains 7 to $13 \%$ protein, 1.4 to $6.0 \%$ fat, 74 to $80 \%$ carbohydrate, $0.81 \%$ ash and $414 \mathrm{kCal} / 100 \mathrm{~g}$ of calorie [2]. In sub-Saharan Africa, about $65 \%$ of maize produced is utilized in the production of different food products such as dumplings, breads, fermented dough, snacks and tortilla [3]. In Nigeria and many West African countries, maize is often consumed in forms of starch, ogi, koko, masa, eko, agidi, ekuru and tuwo [4]. Among these, tuwo, a gel-like dumpling produced by heating maize flour slurry to obtain a smooth dough, is the most important staple food in Northern Nigeria, a region where many ethnic groups such as Hausa, Fulani, Kanuri, Nupe and Jukum are resident [5]. Popularity of maize tuwo has spread to other regions of the country and many West African countries such as Ghana, Togo and Benin.

Acceptability of tuwo is often limited due to poor textural quality which is evident in poor mouldability, high rate of retrogradation and instability of gels after cooling [5]. Consequently, several research efforts have been made to alleviate the challenges. Physical modifications of cereal raw materials such as steaming [6], thermoplastic extrusion [7] and hydrothermal treatment [8] have shown to improve physicochemical properties and sensory attributes of tuwo and other products. However, it is imperative to improve functional properties of flour using techniques that could be easily adopted by poor population of West African countries who are major consumers of tuwo. One of such techniques involves incorporation of stabilizing agent to improve gelling properties and stability of tuwo. Bolade and Adeyemi [6] reported improved textural property of tuwo produced through incorporation of cassava flour into maize flour.

Baobab fruit pulp is an edible component of an underutilized crop known as baobab (Adansonia digitata) tree [9]. Baobab pulp is a rich source of vitamin C (264 mg/100g) and therefore relished as a refreshing drink [10]. It contains $2.16 \%$ protein, $0.4 \%$ lipids, $5.7 \%$ soluble and insoluble fiber, $73.87 \%$ carbohydrate, $7.67 \%$ ash and $307.6 \mathrm{kCal} / \mathrm{g}$ of metabolizable energy [11]. In addition, the main chemical component of baobab pulp which confers it with high viscosity is pectin [12]. There is therefore a new interest in utilization of baobab pulp as gelling or thickening agent in food systems. Ndabikunze et al. [13] reported improved rheological properties of jam stabilized with baobab pulp. They further reported that baobab pulp-stabilized jam compared significantly with commercial pectin-stabilized jam. Furthermore, incorporation of baobab pulp into ogi (a fermented maize product) resulted in improvement of its functional and sensory properties [14].

Objectives of this research were to:

- Determine effects of baobab pulp inclusion and processing methods on functional and colour order properties of maize flour;

- Evaluate stability and sensory attributes of tuwo produced from MF and BPF blends. 


\section{Food Technology}

\section{Materials and methods}

\section{Materials}

Maize grains (Zea mays) (white variety) were obtained from the Teaching and Research Farm of Federal University Wukari, Nigeria while baobab (Adansonia digitata) fruits were collected from baobab trees found within the Forest Reserves of the same University.

\section{Preparation of maize flour}

Maize flour was produced using grit non-soaking (GNS) and grit soaking (GSM) methods described by Bolade et al. [5]. Maize grains were manually cleaned by the removal of stones, damaged kernels and other extraneous materials. The cleaned grains were tempered by sprinkling $5 \%$ water $(\mathrm{v} / \mathrm{w})$ on the grains coupled with thorough mixing. This was followed by decortication of the grains on a locally fabricated corn decorticating machine, in order to obtain maize grits. The grits obtained was divided into 2 equal halves. For the grit nonsoaking method, the first half of the grits was milled using a disc attrition mill (9FC-36, China) followed by sieving using a 40 mesh sieve $(0.450 \mathrm{~mm})$. The flour was packaged in airtight polythene bags (Ziploc, China) and stored at $10 \pm 2{ }^{\circ} \mathrm{C}$ until required. For the grit soaking method, the second half of the grits was soaked in water for 2 hours. Subsequently, the water was drained and the grit was dried in an oven (NL9023A, England) at $50^{\circ} \mathrm{C}$ for 12 hours. The dried grit was milled using a disc attrition mill (9FC-36, China) followed by sieving using a 40 mesh sieve $(0.450 \mathrm{~mm})$. The flour was packaged in airtight polythene bags (Ziplock, China) and stored at $10 \pm 2^{\circ} \mathrm{C}$ until required.

\section{Preparation of baobab pulp flour}

Baobab pulp flour was produced according to the method described by Adejuyitan et al. [14]. Baobab fruits were cracked manually and seeds removed from the pulp by hand. The pulp was then crushed using a blender (CB-8231-D, China), sieved using a 60 mesh sieve $(0.250 \mathrm{~mm})$, packaged in polyethylene bags (Ziploc, China) and stored at $10 \pm 2^{\circ} \mathrm{C}$ until required.

\section{Incorporation of baobab pulp flour into maize flour}

Baobab pulp flour was incorporated separately into maize flours produced by gritsoaking and grit non-soaking methods at concentration levels of $0,5,10 \%(\mathrm{w} / \mathrm{w})$. Blends of $\mathrm{MF}$ and BPF were homogenized in a laboratory mixer (CB-8231-D, China), packaged in polyethylene containers (ZiLock, China) and stored at $10 \pm 2{ }^{\circ} \mathrm{C}$ until required.

\section{Preparation of tuwo}

Maize tuwo was prepared according to an optimized procedure reported by Bolade et al. [5] which gave a final flour to water ratio of 1:3.5 w/v. Slurry was prepared by mixing $100 \mathrm{~g}$ of sample with $437.5 \mathrm{~mL}$ of water. The slurry was added to $1,050 \mathrm{~mL}$ boiling water and the mixture was stirred vigorously until a pap-like consistency was obtained. With continuous stirring, $400 \mathrm{~g}$ of sample was added bit by bit to the boiling pap until a stiff dough was formed. Furthermore, $262.5 \mathrm{~mL}$ of water was added to the gel and covered for 5 minutes without stirring. Subsequently, the gel was stirred vigorously until a smooth consistent gel was formed. The tuwo was served immediately for sensory evaluation. 


\section{Analyses}

Bulk density (loose and packed) and least gelation concentration of blends were determined using the method of Kinsella [15]. Water and oil absorption capacity, swelling capacity and dispersibility of blends were determined using the procedure described by Akpata and Miachi [16]. Clarity of flour pastes was determined by the method described by Yadav et al. [17]. Pasting properties of blends were evaluated using a Brabender viscoamylograph (Newport Scientific Pty Ltd. Warrie-wood NSW, Australia) based on the procedure outlined by Chinma et al. [18]. Colour order characteristics of flour blends were determined using a handheld colorimeter (Chromameter CR-400/410). Sensory analysis of tuwo samples was conducted using a 9 point hedonic scale where 0 and 9 represented dislike extremely and like extremely, respectively. Fifty panelists comprising of $62 \%$ male and $38 \%$ female adults that were familiar with maize tuwo were recruited for the analysis. Samples were coded and served to the panelists at $85^{\circ} \mathrm{C}$ in individual booth under fluorescent light. Samples were rated by panelists for colour, taste, aroma, mouldability, swallowability and general acceptability [6]. Paste stability of tuwo during ambient and refrigerated storage was evaluated by determining syneresis of the paste [19]. A 10\% aqueous suspension of sample $(\mathrm{w} / \mathrm{v})$ was prepared in a screw-capped centrifuge tube and $0.1 \%$ sodium benzoate was added to prevent microbial spoilage. The suspension was heated in a boiling water bath (NL42OS England) at $85^{\circ} \mathrm{C}$ for $30 \mathrm{~min}$ with constant stirring and then cooled rapidly to room temperature $\left(30 \pm 2^{\circ} \mathrm{C}\right)$ on ice bath. After cooling, the paste sample was stored for 5 days at refrigeration $\left(4 \pm 2^{\circ} \mathrm{C}\right)$ and ambient $\left(30 \pm 2^{\circ} \mathrm{C}\right)$ temperatures. Syneresis was determined daily as percentage of water released after centrifugation at $3000 \times \mathrm{g}$ for 15 minutes. All experiments were conducted in triplicates. Data obtained were subjected to 2-way analysis of variance with processing method and blend ratio serving as independent variables. Means were separated with Duncan Multiple Range Test at 5\% level of significance. These were achieved with the aid of Statistical Package for Social Scientists (SPSS IBM Corp. USA), version 23.

\section{Results and discussion}

\section{Effect of baobab pulp inclusion on the functional properties of maize flour}

Table 1 shows the functional properties of MF as influenced by processing methods and level of baobab pulp (BPF) inclusion. Loose bulk density was significantly $(\mathrm{p}<0.05)$ influenced by processing methods and concentration of BPF in the blends. Inclusion of 5\% BPF in MF produced by GNS method did not cause any significant ( $p>0.05$ ) change in loose bulk density, however, a significant $(\mathrm{p}<0.05)$ increase was recorded in the blend containing $10 \%$ BPF. Significant $(\mathrm{p}<0.05)$ increase in loose bulk density at 5\% BPF level was recorded in MF produced by GSM method. Inclusion of $10 \%$ BPF into MF produced by GNS resulted in a significant $(\mathrm{p}<0.05)$ increase in packed bulk density. Significant change was not observed at lower concentration (5\% BPF) in MF produced by both GSM and GNS methods. Maize flour and BPF blends produced using GSM method had significantly lower $(p<0.05)$ loose and packed bulk density than the corresponding blends produced by GNS. Reduction in bulk density could be due to breakdown of large organic molecules consequent to percolation of water into grits during soaking operation [20]. Soaking also caused a significant reduction in bulk density of millet [21]. 
Functional properties of maize and baobab pulp flour blends

\begin{tabular}{|c|c|c|c|c|c|c|c|c|c|}
\hline 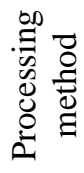 & 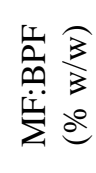 & 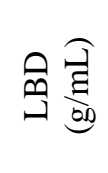 & 坣 & 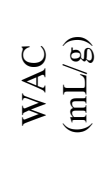 & 这 & 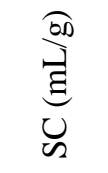 & 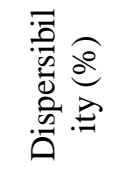 & 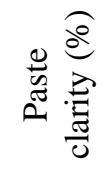 & 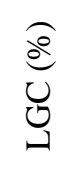 \\
\hline \multirow[t]{3}{*}{ GNS } & 100:0 & $\begin{array}{c}0.48^{\mathrm{ab}} \pm \\
0.02\end{array}$ & $\begin{array}{c}0.70^{\mathrm{b}} \pm \\
0.04\end{array}$ & $\begin{array}{c}2.31^{\mathrm{b}} \pm \\
0.04\end{array}$ & $\begin{array}{c}2.31^{\mathrm{ab}} \pm \\
0.04\end{array}$ & $\begin{array}{c}5.82^{\mathrm{ab}} \pm \\
0.06\end{array}$ & $\begin{array}{c}50.53^{\mathrm{c}} \pm \\
2.89\end{array}$ & $\begin{array}{c}4.50^{\mathrm{a}} \pm \\
1.92\end{array}$ & 8.00 \\
\hline & 95:5 & $\begin{array}{c}0.49^{\mathrm{ab}} \pm \\
0.02\end{array}$ & $\begin{array}{c}0.72^{\mathrm{b}} \pm \\
0.01\end{array}$ & $\begin{array}{c}2.34^{\mathrm{ab}} \pm \\
0.11\end{array}$ & $\begin{array}{c}2.14^{\mathrm{bc}} \pm \\
0.06\end{array}$ & $\begin{array}{c}5.80^{\mathrm{ab}} \pm \\
0.04\end{array}$ & $\begin{array}{c}54.64^{\mathrm{bc}} \pm \\
2.47\end{array}$ & $\begin{array}{c}1.88^{\mathrm{b}} \pm \\
0.13\end{array}$ & 8.00 \\
\hline & $90: 10$ & $\begin{array}{c}0.53^{\mathrm{a}} \pm \\
0.04\end{array}$ & $\begin{array}{c}0.77^{\mathrm{a}} \pm \\
0.03\end{array}$ & $\begin{array}{c}2.49^{\mathrm{a}} \pm \\
0.02\end{array}$ & $\begin{array}{c}2.14^{\mathrm{bc}} \pm \\
0.07\end{array}$ & $\begin{array}{c}5.85^{\mathrm{a}} \pm \\
0.06\end{array}$ & $\begin{array}{c}59.55^{\mathrm{a}} \pm \\
0.18\end{array}$ & $\begin{array}{c}1.86^{\mathrm{b}} \pm \\
0.88\end{array}$ & 6.00 \\
\hline \multirow[t]{3}{*}{ GSM } & 100:0 & $\begin{array}{c}0.45^{\mathrm{b}} \pm \\
0.01\end{array}$ & $\begin{array}{c}0.68^{\mathrm{b}} \pm \\
0.03\end{array}$ & $\begin{array}{c}2.34^{\mathrm{ab}} \pm \\
0.06\end{array}$ & $\begin{array}{c}2.34^{\mathrm{a}} \pm \\
0.13\end{array}$ & $\begin{array}{c}5.82^{\mathrm{ab}} \pm \\
0.05\end{array}$ & $\begin{array}{c}57.07^{\mathrm{b}} \pm \\
0.96\end{array}$ & $\begin{array}{c}2.99^{\mathrm{ab}} \pm \\
0.68\end{array}$ & 4.00 \\
\hline & $95: 5$ & $\begin{array}{c}0.47^{\mathrm{ab}} \pm \\
0.01\end{array}$ & $\begin{array}{c}0.71^{\mathrm{b}} \pm \\
0.01\end{array}$ & $\begin{array}{c}2.19^{\mathrm{b}} \pm \\
0.06\end{array}$ & $\begin{array}{c}1.91^{\mathrm{d}} \pm \\
0.01\end{array}$ & $\begin{array}{c}5.44^{\mathrm{b}} \pm \\
0.19\end{array}$ & $\begin{array}{c}61.66^{\mathrm{a}} \pm \\
4.77\end{array}$ & $\begin{array}{c}2.11^{\mathrm{ab}} \pm \\
0.51\end{array}$ & 2.00 \\
\hline & $90: 10$ & $\begin{array}{c}0.48^{\mathrm{ab}} \pm \\
0.03\end{array}$ & $\begin{array}{c}0.71^{\mathrm{b}} \pm \\
0.04\end{array}$ & $\begin{array}{c}2.30^{\mathrm{b}} \pm \\
0.01\end{array}$ & $\begin{array}{c}1.99^{\mathrm{cd}} \pm \\
0.00\end{array}$ & $\begin{array}{c}5.82^{\mathrm{ab}} \pm \\
0.32\end{array}$ & $\begin{array}{c}52.99^{c} \pm \\
5.11\end{array}$ & $\begin{array}{c}3.15^{\mathrm{ab}} \pm \\
0.12\end{array}$ & 2.00 \\
\hline
\end{tabular}

Values are means \pm standard deviations of triplicate scores. Means within a column with different superscripts were significantly $(\mathrm{p}<0.05)$ different. GNS- grit non-soaking method; GSM- grit soaking method; MF-maize flour; BPF-baobab pulp flour; LBD- loose bulk density; PBD- packed bulk density; WAC-water absorption capacity; OAC-oil absorption capacity; SC-swelling capacity; LGC-least gelation concentration.

Water absorption capacity of MF produced by the GNS method increased significantly $(\mathrm{p}<0.05)$ with increasing level of BPF inclusion. According to Seena and Sridha [22], high water absorption causes high retention of water without dissolution of protein, thus increasing the body and viscosity of gel. Conversely, inclusion of BPF into MF produced by the GSM method reduced water absorption capacity. Bolaji et al. [23] also reported that water absorption capacity of ogi (a fermented maize product) reduced with increase in soaking time of maize grains. Variation observed in water absorption capacity could be due to differing particle sizes and starch components of the BPF and MF blends. According to Adegunwa et al. [24], water absorption capacity is dependent on factors such as particle size, amylose/amylopectin ratio and molecular structures of component flours. Grit soaking caused a significant $(\mathrm{p}<0.05)$ increase in oil absorption capacity. This corroborated the findings of Ocheme et al. [21] who also reported that soaking of millet grains increased oil absorption capacity of millet flour. Inclusion of BPF into MF caused significant $(p<0.05)$ reduction in oil absorption capacity. This might be due to conformational imbalance between hydrophilic and hydrophobic components of the blends [25]. Ten percent substitution of BPF into MF produced using GNS method increased swelling capacity while the same substitution level did not have significant ( $p>0.05$ ) effect on MF produced using GSM method. The increase in swelling capacity may be attributed to increased hydration of starch [18]. Irrespective of method of MF production, BPF incorporation into MF increased percentage dispersibility significantly $(p<0.05)$. This implies better reconstitution of flour in water prior to heating. According to Adebowale et al. [26], reconstitution of flour in water is dependent on flour dispersibility. Significantly $(\mathrm{p}<0.05)$ higher paste clarity $(4.50 \%)$ was recorded in flour produced by GNS method compared to the value $(2.99 \%)$ recorded for flour produced by GSM method. This difference could be due to variation in dispersibility of flours produced by both methods. According to Yadav et al. [17], paste clarity is dependent on dispersion and 
retrogradation tendencies of starches. Inclusion of BPF significantly $(\mathrm{p}<0.05)$ reduced paste clarity in MF produced by GNS method, however, no significant ( $p>0.05)$ change was observed in flour produced by GSM method as a result of BPF inclusion. This phenomenon suggested reduction in retrogradation tendency of MF produced by GSM method, which probably due to grit soaking operation. Soaking is often associated with changes in metabolic activities which result in modification of physicochemical and nutritional qualities of food products [21, 27].

Processing methods affected gelling properties of MF. Maize flour produced using GSM method gelled at $4 \%$ while the minimum gelling concentration for MF produced by the GNS method was $8 \%$. Lower gelation concentration attributed to MF produced by GSM method could be due to improved hydration of starch consequent to the soaking operation. This is advantageous because improved gelation properties reduce the amount of heat energy required during preparation of tuwo. It will also reduce cooking time. Inclusion of BPF into MF further improved the gelation properties. Inclusion of 5\% BPF into MF produced by GSM method lowered gelation concentration to $2 \%$ while inclusion of $10 \%$ BPF into MF produced by the GNS method reduced gelation concentration to $4 \%$. This clearly showed stabilizing ability of BPF whose inclusion into MF probably increased solubilization of starch and/or protein molecules which resulted in rearrangement of functional groups [28]. Adejuyitan et al. [14] also reported improved gelation property of ogi (a fermented maize food) as a result of inclusion of baobab pulp.

\section{Effect of baobab pulp inclusion on the pasting properties of maize flour}

Samples showed different pasting properties (Table 2) as a result of different processing methods and baobab pulp level. Significantly $(\mathrm{p}<0.05)$ higher peak viscosity was recorded for MF produced by GSM method compared to the corresponding MF produced by GNS method, for example $100 \% \mathrm{MF}$ produced by GNS method had a peak viscosity of 473.83RVA while 100\% MF produced by GSM method had a peak viscosity of 792.63RVA.

Table 2

Pasting properties of maize and baobab flour blends

\begin{tabular}{|c|c|c|c|c|c|c|c|}
\hline Method & $\begin{array}{c}\mathrm{MF}: \\
\mathrm{BPF} \\
(\% \mathrm{w} / \mathrm{w})\end{array}$ & $\begin{array}{c}\text { Peak viscosity } \\
\text { (RVU) }\end{array}$ & $\begin{array}{c}\text { Breakdown } \\
\text { (RVU) }\end{array}$ & $\begin{array}{c}\text { Final } \\
\text { viscosity } \\
\text { (RVU) }\end{array}$ & $\begin{array}{c}\text { Setback } \\
\text { (RVU) }\end{array}$ & $\begin{array}{c}\text { Peak } \\
\text { time (mins) }\end{array}$ & $\begin{array}{c}\text { Pasting } \\
\text { temperature } \\
\left({ }^{\circ} \mathrm{C}\right)\end{array}$ \\
\hline \multirow[t]{3}{*}{ GNS } & 100:0 & $\begin{array}{c}473.83^{\mathrm{f}} \pm \\
1.06\end{array}$ & $\begin{array}{c}436.54^{\mathrm{a}} \pm \\
28.58\end{array}$ & $\begin{array}{c}578.42^{\mathrm{e}} \pm \\
5.19 \\
\end{array}$ & $\begin{array}{c}541.13^{\mathrm{c}} \pm \\
40.13\end{array}$ & $\begin{array}{c}5.73^{\mathrm{a}} \pm \\
0.06\end{array}$ & $\begin{array}{c}87.68^{\mathrm{a}} \pm \\
0.61\end{array}$ \\
\hline & $95: 5$ & $\begin{array}{c}549.88^{\mathrm{d}} \pm \\
4.77\end{array}$ & $\begin{array}{c}507.63^{\mathrm{a}} \pm \\
0.36\end{array}$ & $\begin{array}{c}598.54^{\mathrm{d}} \pm \\
6.78\end{array}$ & $\begin{array}{c}556.29^{c} \pm \\
3.36\end{array}$ & $\begin{array}{c}5.45^{\mathrm{b}} \pm \\
0.07\end{array}$ & $\begin{array}{c}85.22^{\mathrm{ab}} \pm \\
0.00\end{array}$ \\
\hline & $90: 10$ & $\begin{array}{c}542.88^{\mathrm{e}} \pm \\
1.89\end{array}$ & $\begin{array}{c}504.88^{\mathrm{a}} \pm \\
0.06\end{array}$ & $\begin{array}{c}581.33^{\mathrm{e}} \pm \\
3.42\end{array}$ & $\begin{array}{c}543.33^{\mathrm{c}} \pm \\
1.59\end{array}$ & $5.33^{b c} \pm 0.03$ & $\begin{array}{c}82.73^{\mathrm{b}} \pm \\
0.56\end{array}$ \\
\hline \multirow[t]{3}{*}{ GSM } & 100:0 & $\begin{array}{c}753.13^{\mathrm{b}} \pm \\
1.71\end{array}$ & $\begin{array}{c}626.33^{\mathrm{a}} \pm \\
0.82\end{array}$ & $\begin{array}{c}905.00^{\mathrm{a}} \pm \\
0.94\end{array}$ & $\begin{array}{c}778.20^{\mathrm{a}} \pm \\
1.59\end{array}$ & $\begin{array}{c}5.13^{\mathrm{d}} \pm \\
0.09\end{array}$ & $\begin{array}{c}79.61^{\mathrm{c}} \pm \\
0.90\end{array}$ \\
\hline & $95: 5$ & $\begin{array}{c}703.75^{\mathrm{c}} \pm \\
3.65\end{array}$ & $\begin{array}{c}610.71^{\mathrm{a}} \pm \\
1.59\end{array}$ & $\begin{array}{c}779.88^{\mathrm{c}} \pm \\
8.54\end{array}$ & $\begin{array}{c}686.84^{\mathrm{b}} \pm \\
6.48\end{array}$ & $\begin{array}{c}5.33^{\mathrm{bc}} \pm \\
0.00\end{array}$ & $\begin{array}{c}80.00^{c} \pm \\
1.90\end{array}$ \\
\hline & $90: 10$ & $\begin{array}{c}792.63^{\mathrm{a}} \pm \\
0.41\end{array}$ & $\begin{array}{c}391.17^{\mathrm{a}} \pm \\
445.2\end{array}$ & $\begin{array}{c}850.54^{\mathrm{b}} \pm \\
0.88\end{array}$ & $\begin{array}{c}449.08^{\mathrm{d}} \pm \\
0.24\end{array}$ & $\begin{array}{c}5.27^{\mathrm{cd}} \pm \\
0.09\end{array}$ & $\begin{array}{c}78.21^{\mathrm{c}} \pm \\
1.48\end{array}$ \\
\hline
\end{tabular}

Values are means \pm standard deviations of triplicate scores. Means within a column with different superscripts were significantly $(\mathrm{p}<0.05)$ different. GNS- grit non-soaking method; GSM- grit soaking method; MF- maize flour; BPF- baobab pulp flour. 
Higher peak viscosity recorded for MF produced by the GSM method could be due to higher granule swelling brought about by soaking operation. According to Oluwamukomi and Jolayemi [29], high swelling index is correlated with high peak viscosity. Bolade and Adeyemi [6] also reported increase in peak viscosity of heat-moisture pretreated maize flour. In addition, peak viscosity significantly $(\mathrm{p}<0.05)$ increased with increasing BPF level in MF. This could be as a result of increase in water binding activity of the flour due to the inclusion of BPF. This would contribute to better quality of tuwo since peak viscosity is often associated with final product quality [30].

There was no significant ( $p>0.05$ ) difference among the samples in terms of breakdown viscosity. Lowest breakdown viscosity of 391.17RVU was recorded for the blend of MF produced by GSM and 10\% BPF. This suggested good stability of the paste owning to its ability to withstand shear-thinning, consequent to prolonged heating [31]. Blends produced by GSM method had a final viscosity of 905.00RVU, compared to a significantly $(\mathrm{p}<0.05)$ lower value of 578.42RVU recorded for flour produced by GNS method. Inclusion of BPF caused significant $(\mathrm{p}<0.05)$ reduction of final viscosity in flours produced by the GSM method, however, inclusion resulted in increase in final viscosity of flours produced by GNS method. Setback viscosity also followed the same trend. This corroborated finding of Bolade et al. [5] who also reported reduction in setback viscosity of maize flour produced by the GSM method. Reduction in setback viscosity of blends of MF produced by GSM and BPF could be attributed to increased enzymatic activity during grit soaking. This probably led to partial hydrolysis of starch molecules [32]. This could go a long way in reducing retrogradation of pastes [33].

Peak time ranged from 5.13 to 5.73 minutes with $100 \%$ MF produced by GSM method and $100 \%$ MF produced by GNS having lowest and highest values, respectively. Inclusion of BPF caused a significant $(\mathrm{p}<0.05)$ reduction in peak time of MF produced by GNS method. Also, grit soaking significantly $(\mathrm{p}<0.005)$ reduced peak time. In the same vein, pasting temperature was significantly $(\mathrm{p}<0.005)$ reduced by the inclusion of BPF into MF produced by GNS method, however, no significant $(\mathrm{p}>0.05)$ change was observed among samples produced by GSM method. Reduction in peak time and temperature will reduce the total energy and time required for tuwo preparation [18].

\section{Effect of baobab pulp inclusion on colour order properties of maize flour}

Table 3 shows variation in colour properties of MF as influenced by processing methods and BPF inclusion. $L^{*}$ ranged from 77.03 to 85.97 . There was no significant $(\mathrm{p}>0.05$ ) difference in $\mathrm{L}^{*}$ among the control samples i.e. 100\% GNS and GSM. This contradicted the report of Bolade et al. [5] who reported lower L* value for MF produced by GSM. Inclusion of BPF into MF caused a significant $(\mathrm{p}<0.05)$ reduction in $\mathrm{L}^{*}$. The reduction might have been due to the effect of baobab pulp which has a creamy white colour [9].

Low $\mathrm{a} *$ ranging from -0.10 to 1.26 were recorded for the samples. These low values imply deviation of the samples from green and red. Bolade et al. [6] also reported low a* ranging from -0.08 to -0.18 for pre-gelatinized MF. $b^{*}$ increased significantly $(p<0.05)$ with increasing level of BPF in MF. This implies that colour of the samples tended towards yellow due to the presence of baobab pulp. Hue angle varied between 59.33 and 88.20. This showed deviation towards yellow colour. The movement of hue angle from $0^{\circ}$ to $90^{\circ}$ indicates colour change from red to yellow [5]. Chroma and colour intensity ranged from 6.14 to 10.17 and 10.10 to 20.39 , respectively. Inclusion of BPF increased these colour parameters significantly $(\mathrm{p}<0.05)$. Chroma and colour intensity are indices for colour purity [31], therefore, inclusion of BPF improved MF in that regard. 
Table 3

Colou order properties of maize and baobab pulp flour blends

\begin{tabular}{|l|c|c|c|c|c|c|c|}
\hline $\begin{array}{c}\text { Processing } \\
\text { method }\end{array}$ & $\begin{array}{c}\text { MF:BPF } \\
\text { \% w/w })\end{array}$ & $\mathrm{L}^{*}$ & $\mathrm{a}^{*}$ & $\mathrm{~b}^{*}$ & $\begin{array}{c}\text { Hue } \\
\text { angle }\end{array}$ & Chroma & $\begin{array}{c}\text { Colour } \\
\text { intensity }\end{array}$ \\
\hline GNS & $100: 0$ & $\begin{array}{c}85.97^{\mathrm{a}} \pm \\
0.82\end{array}$ & $\begin{array}{c}-0.30^{\mathrm{f}} \\
\pm 0.01\end{array}$ & $\begin{array}{c}9.64^{\mathrm{d}} \pm \\
0.13\end{array}$ & $\begin{array}{c}88.20^{\mathrm{a}} \pm \\
0.08\end{array}$ & $\begin{array}{c}6.14^{\mathrm{d}} \pm \\
0.13\end{array}$ & $\begin{array}{c}10.10^{\mathrm{c}} \pm \\
0.57\end{array}$ \\
\hline & $95: 5$ & $\begin{array}{c}75.30^{\mathrm{d}} \pm \\
2.17\end{array}$ & $\begin{array}{c}0.43^{\mathrm{d}} \pm \\
0.02\end{array}$ & $\begin{array}{c}11.54^{\mathrm{c}} \pm \\
0.36\end{array}$ & $\begin{array}{c}87.86^{\mathrm{a}} \pm \\
0.17\end{array}$ & $\begin{array}{c}8.12^{\mathrm{c}} \pm \\
0.35\end{array}$ & $\begin{array}{c}20.39^{\mathrm{a}} \pm \\
1.85\end{array}$ \\
\hline & $90: 10$ & $\begin{array}{c}82.18^{\mathrm{b}} \pm \\
0.42\end{array}$ & $\begin{array}{c}1.05^{\mathrm{b}} \pm \\
0.03\end{array}$ & $\begin{array}{c}14.94^{\mathrm{a}} \pm \\
0.09\end{array}$ & $\begin{array}{c}85.98^{\mathrm{a}} \pm \\
0.09\end{array}$ & $\begin{array}{c}11.58^{\mathrm{a}} \pm \\
0.10\end{array}$ & $\begin{array}{c}16.54^{\mathrm{b}} \pm \\
0.24\end{array}$ \\
\hline & $100: 0$ & $\begin{array}{c}85.15^{\mathrm{a}} \pm \\
2.14\end{array}$ & $\begin{array}{c}-0.10^{\mathrm{e}} \\
\pm 0.09\end{array}$ & $\begin{array}{c}9.14^{\mathrm{d}} \pm \\
0.46\end{array}$ & $\begin{array}{c}59.33^{\mathrm{b}} \pm \\
51.38\end{array}$ & $\begin{array}{c}5.67^{\mathrm{d}} \pm \\
0.47\end{array}$ & $\begin{array}{c}10.57^{\mathrm{c}} \pm \\
1.47\end{array}$ \\
\hline & $95: 5$ & $\begin{array}{c}79.66^{\mathrm{bc}^{\mathrm{c}}} \pm \\
0.93\end{array}$ & $\begin{array}{c}0.64^{\mathrm{c}} \pm \\
0.07\end{array}$ & $\begin{array}{c}11.91^{\mathrm{c}} \pm \\
0.16\end{array}$ & $\begin{array}{c}86.94^{\mathrm{a}} \pm \\
0.33\end{array}$ & $\begin{array}{c}8.52^{\mathrm{c}} \pm \\
0.16\end{array}$ & $\begin{array}{c}16.67^{\mathrm{b}} \pm \\
0.73\end{array}$ \\
\hline & $90: 10$ & $\begin{array}{c}77.03^{\mathrm{cd}} \pm \\
1.77\end{array}$ & $\begin{array}{c}1.26^{\mathrm{a}} \pm \\
0.01\end{array}$ & $\begin{array}{c}13.77^{\mathrm{b}} \pm \\
0.38\end{array}$ & $\begin{array}{c}84.78^{\mathrm{a}} \pm \\
0.14\end{array}$ & $\begin{array}{c}10.47^{\mathrm{b}} \pm \\
0.37\end{array}$ & $\begin{array}{c}19.95^{\mathrm{a}} \pm \\
1.39\end{array}$ \\
\hline
\end{tabular}

Values are means \pm standard deviations of 3 replications. Means within a column with different superscripts were significantly $(\mathrm{p}<0.05)$ different. GNS = grit non-soaking method, GSM = grit soaking method, $\mathrm{MF}=$ maize flour, $\mathrm{BPF}=$ baobab pulp flour.

\section{Effect of baobab pulp inclusion on sensory properties of maize flour}

Effect of processing methods and inclusion of baobab pulp on sensory properties of maize based tuwo is presented in Table 4.

Table 4

Sensory properties of tuwo prepared from blends of maize and baobab pulp flours

\begin{tabular}{|c|c|c|c|c|c|c|c|}
\hline 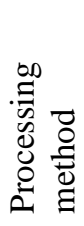 & 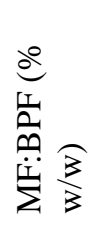 & $\frac{\overline{0}}{0}$ & 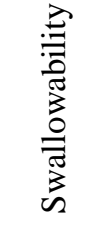 & 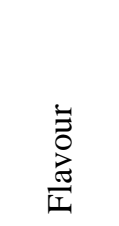 & 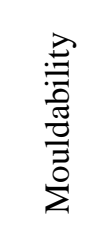 & 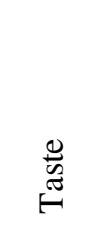 & 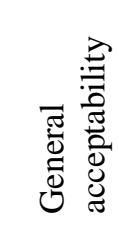 \\
\hline \multirow[t]{3}{*}{ GNS } & 100:0 & $\begin{array}{c}8.36^{\mathrm{a}} \pm \\
0.76\end{array}$ & $\begin{array}{c}7.64^{\mathrm{a}} \pm \\
1.11\end{array}$ & $\begin{array}{c}7.76^{\mathrm{a}} \pm \\
0.88\end{array}$ & $\begin{array}{c}7.04^{\mathrm{ab}} \pm \\
1.10\end{array}$ & $\begin{array}{c}7.60^{\mathrm{a}} \pm \\
1.15\end{array}$ & $\begin{array}{l}7.80^{\mathrm{a}} \pm \\
1.12\end{array}$ \\
\hline & 95:5 & $\begin{array}{c}7.36^{\mathrm{c}} \pm \\
1.32\end{array}$ & $\begin{array}{c}6.16^{\mathrm{b}} \pm \\
2.03\end{array}$ & $\begin{array}{c}6.60^{\mathrm{c}} \pm \\
1.68\end{array}$ & $\begin{array}{c}7.04^{\mathrm{ab}} \pm \\
1.40\end{array}$ & $\begin{array}{c}6.08^{\mathrm{b}} \pm \\
2.18\end{array}$ & $\begin{array}{l}6.68^{\mathrm{bc}} \pm \\
1.68\end{array}$ \\
\hline & $90: 10$ & $\begin{array}{c}7.44^{\mathrm{c}} \pm \\
1.23\end{array}$ & $\begin{array}{c}6.12^{\mathrm{b}} \pm \\
2.11\end{array}$ & $\begin{array}{c}6.56^{\mathrm{c}} \pm \\
1.71\end{array}$ & $\begin{array}{c}6.52^{\mathrm{b}} \pm \\
1.64\end{array}$ & $\begin{array}{c}5.88^{\mathrm{b}} \pm \\
1.88\end{array}$ & $\begin{array}{l}6.52^{\mathrm{c}} \pm \\
1.90\end{array}$ \\
\hline \multirow[t]{3}{*}{ GSM } & 100:0 & $\begin{array}{c}8.12^{\mathrm{ab}} \pm \\
1.09\end{array}$ & $\begin{array}{c}7.96^{\mathrm{a}} \pm \\
1.02\end{array}$ & $\begin{array}{c}7.44^{\mathrm{ab}} \pm \\
1.16\end{array}$ & $\begin{array}{c}7.44^{\mathrm{a}} \pm \\
0.92\end{array}$ & $\begin{array}{c}7.52^{\mathrm{a}} \pm \\
1.50\end{array}$ & $\begin{array}{l}7.88^{\mathrm{a}} \pm \\
1.13 \\
\end{array}$ \\
\hline & 95:5 & $\begin{array}{c}7.36^{\mathrm{c}} \pm \\
1.25\end{array}$ & $\begin{array}{c}7.36^{\mathrm{a} \pm} \\
1.22\end{array}$ & $\begin{array}{c}6.76^{\mathrm{bc}} \pm \\
1.20\end{array}$ & $\begin{array}{c}7.08^{\mathrm{ab}} \pm \\
1.32\end{array}$ & $\begin{array}{c}7.44^{\mathrm{a}} \pm \\
1.47\end{array}$ & $\begin{array}{l}7.28^{\mathrm{abc}} \pm \\
1.17\end{array}$ \\
\hline & $90: 10$ & $\begin{array}{c}7.56^{\mathrm{bc}} \pm \\
1.12\end{array}$ & $\begin{array}{c}7.60^{\mathrm{a}} \pm \\
1.08\end{array}$ & $\begin{array}{c}7.24^{\mathrm{abc}} \pm \\
1.16\end{array}$ & $\begin{array}{c}7.04^{\mathrm{ab}} \pm \\
1.59\end{array}$ & $\begin{array}{c}7.16^{\mathrm{a}} \pm \\
1.57\end{array}$ & $\begin{array}{l}7.48^{\mathrm{ab}} \pm \\
1.05\end{array}$ \\
\hline
\end{tabular}

Values are means \pm standard deviations of 50 scores. Means within a column with different superscripts were significantly $(\mathrm{p}<0.05)$ different. GNS- grit non-soaking method; GSM- grit soaking method; MFmaize flour; BPF- baobab pulp flour. 
In terms of colour, significantly $(\mathrm{p}<0.05)$ higher scores $(8.36$ and 8.12 for $100 \%$ GNS and GSM, respectively) were recorded for the control samples. Nonetheless, appreciable high scores ranging from 7.36 to 7.56 were recorded for samples containing different levels of BPF. Inclusion of BPF reduced colour acceptability probably because the panelists were familiar with tuwo prepared from 100\% MF. Adejuyitan et al. [14] also reported reduction in colour acceptability of $o g i$ fortified with baobab pulp. Inclusion of 5 and $10 \%$ BPF into MF produced by GSM method compared significantly $(\mathrm{p}<0.05)$ with the control samples in terms of swallowability. Inclusion of baobab pulp reduced flavour of tuwo probably due to impartation of sour taste into the product. The control sample produced by GSM method had highest score for mouldability. This corroborated earlier finding of Bolade [33] who reported better textural quality for maize based tuwo produced by GSM method. Inclusion of $10 \%$ BPF into MF produced by GSM method gave a tuwo with high mouldability (7.04 to 7.08) which compared significantly $(\mathrm{p}<0.05)$ with the control sample produced by GNS. In terms of taste, there was no significant ( $\mathrm{p}>0.05$ ) difference among tuwo samples produced by GSM, however, inclusion of BPF into MF caused significant $(\mathrm{p}<0.05)$ reduction in taste of tuwo prepared from blends of BPF and MF produced by GNS method. Similar trend was observed for general acceptability.

\section{Effect of baobab pulp inclusion on the stability of maize tuwo}

Stability (expressed in percentage syneresis) of tuwo as influenced by baobab pulp inclusion under ambient and refrigeration storage conditions is presented in Table 5. Analysis conducted immediately after tuwo preparation showed significantly $(\mathrm{p}<0.05)$ lower syneresis for tuwo containing BPF in both processing methods. The same trend was observed throughout the period of storage for both storage conditions. This could be due to the binding of water molecules within gel matrix formed between starch molecules of maize flour and pectin of baobab pulp. Baobab pulp has been reported to be rich in pectin which has high water binding property [13].

Samples produced using GSM method showed better stability than those produced using GNS method. For example, at the end of the first day of ambient storage, syneresis ranged from 5.6 to $16.3 \%$ and 2.5 to $10.2 \%$ for tuwo produced using GNS and GSM methods, respectively. Furthermore, syneresis ranged from 2.5 to $14.9 \%$ and 1.8 to $2.2 \%$ under refrigeration storage condition for tuwo produced using GNS and GSM methods, respectively. This could be due to increased gel firmness in tuwo produced by GSM which could be attributed to reduction in amylopectin crystallization and consequent formation of amylose matrix gel effected by grit soaking operation [19].

Tuwo stored under refrigerated conditions showed improved paste stability compared to those stored at ambient condition. Reduced exclusion of water in tuwo stored at refrigeration condition could be due to reduction in inter and intra molecular hydrogen bonding which probably caused lower retrogradation rate [34]. For both storage conditions, syneresis increased with storage time. This is in line with the findings of Yadav et al. [17] who reported increase in syneresis of banana, potato and rice starch blends with storage time. However, tuwo samples stored at refrigeration temperature showed a sharp reduction in syneresis after 4 days of refrigeration. This might be due to reduction in crystallite formation which probably resulted to reduction in water separation from the gel matrix [19]. 
Effect of baobab pulp inclusion on the stability of maize tuwo under storage

\begin{tabular}{|c|c|c|c|c|c|c|c|}
\hline \multirow{2}{*}{$\begin{array}{c}\text { Processing } \\
\text { method }\end{array}$} & \multirow{2}{*}{$\begin{array}{c}\text { MF:BPF } \\
(\% \mathrm{w} / \mathrm{w})\end{array}$} & \multicolumn{6}{|c|}{ Syneresis (\%) } \\
\hline & & Day 0 & Day 1 & Day 2 & Day 3 & Day 4 & Day 5 \\
\hline & & \multicolumn{6}{|c|}{ Ambient storage $\left(28 \pm 2^{\circ} \mathrm{C}\right)$} \\
\hline \multirow[t]{3}{*}{ GNS } & 100:0 & $\begin{array}{c}7.0^{\mathrm{a}} \pm \\
1.41\end{array}$ & $\begin{array}{c}16.3^{\mathrm{a}} \pm \\
1.27\end{array}$ & $\begin{array}{c}19.8^{\mathrm{a}} \pm \\
1.70\end{array}$ & $\begin{array}{c}22.5^{\mathrm{b}} \pm \\
1.56\end{array}$ & $\begin{array}{c}39.2^{\mathrm{a}} \pm \\
1.41\end{array}$ & $\begin{array}{c}72.0^{\mathrm{a}} \pm \\
1.41\end{array}$ \\
\hline & $95: 5$ & $\begin{array}{l}7.8^{\mathrm{c}} \pm \\
0.28\end{array}$ & $\begin{array}{c}10.1^{\mathrm{a}} \pm \\
1.41\end{array}$ & $\begin{array}{c}10.0^{\mathrm{b}} \pm \\
1.41\end{array}$ & $\begin{array}{l}5.0^{\mathrm{d}} \pm \\
0.57\end{array}$ & $\begin{array}{c}5.9^{\mathrm{d}} \pm \\
1.56\end{array}$ & $\begin{array}{c}60.4^{\mathrm{b}} \pm \\
1.56\end{array}$ \\
\hline & 90:10 & $\begin{array}{l}1.0^{\mathrm{c}} \pm \\
0.57\end{array}$ & $\begin{array}{c}5.6^{\mathrm{b}} \pm \\
1.98\end{array}$ & $\begin{array}{c}12.9^{\mathrm{b}} \pm \\
1.41\end{array}$ & $\begin{array}{l}3.5^{\mathrm{d}} \pm \\
1.27\end{array}$ & $\begin{array}{c}4.7^{\mathrm{d}} \pm \\
1.27\end{array}$ & $\begin{array}{c}28.5^{\mathrm{d}} \pm \\
1.84\end{array}$ \\
\hline \multirow[t]{4}{*}{ GSM } & 100:0 & $\begin{array}{c}3.9^{\mathrm{b}} \pm \\
0.28\end{array}$ & $\begin{array}{c}10.2^{\mathrm{a}} \pm \\
1.70\end{array}$ & $\begin{array}{c}18.9^{\mathrm{a}} \pm \\
1.41\end{array}$ & $\begin{array}{c}27.7^{\mathrm{a}} \pm \\
1.70\end{array}$ & $\begin{array}{c}24.0^{\mathrm{b}} \pm \\
0.71\end{array}$ & $\begin{array}{c}33.3^{\mathrm{c}} \pm \\
1.70\end{array}$ \\
\hline & $95: 5$ & $\begin{array}{l}1.0^{\mathrm{a}} \pm \\
0.28\end{array}$ & $\begin{array}{c}2.5^{\mathrm{b}} \pm \\
1.41\end{array}$ & $\begin{array}{c}17.0^{\mathrm{a}} \pm \\
1.41\end{array}$ & $\begin{array}{c}22.8^{\mathrm{b}} \pm \\
1.84\end{array}$ & $\begin{array}{c}17.8^{\mathrm{c}} \pm \\
1.56\end{array}$ & $\begin{array}{c}7.0^{\mathrm{e}} \pm \\
1.41\end{array}$ \\
\hline & $90: 10$ & $\begin{array}{l}1.0^{\mathrm{c}} \pm \\
0.57\end{array}$ & $\begin{array}{c}10.8^{\mathrm{a}} \pm \\
1.70\end{array}$ & $\begin{array}{c}12.8^{\mathrm{b}} \pm \\
1.41\end{array}$ & $\begin{array}{c}13.9^{\mathrm{c}} \pm \\
1.41\end{array}$ & $\begin{array}{c}17.8^{\mathrm{c}} \pm \\
1.41\end{array}$ & $\begin{array}{c}8.9^{\mathrm{e}} \pm \\
1.56\end{array}$ \\
\hline & & \multicolumn{6}{|c|}{ Refrigeration storage $\left(4 \pm 2^{\circ} \mathrm{C}\right)$} \\
\hline \multirow[t]{3}{*}{ GNS } & 100:0 & $\begin{array}{l}7.0^{\mathrm{a}} \pm \\
1.41\end{array}$ & $\begin{array}{c}14.9^{\mathrm{a}} \pm \\
1.70\end{array}$ & $\begin{array}{c}16.8^{\mathrm{b}} \pm \\
1.70\end{array}$ & $\begin{array}{c}11.0^{\mathrm{c}} \pm \\
1.41\end{array}$ & $\begin{array}{l}7.9^{\mathrm{c}} \pm \\
1.56\end{array}$ & $\begin{array}{c}5.0^{\mathrm{cd}} \pm \\
1.41\end{array}$ \\
\hline & $95: 5$ & $\begin{array}{c}7.8^{\mathrm{a}} \pm \\
1.56\end{array}$ & $\begin{array}{c}13.8^{\mathrm{b}} \pm \\
1.70\end{array}$ & $\begin{array}{c}10.0^{\mathrm{c}} \pm \\
1.56\end{array}$ & $\begin{array}{c}16.0^{\mathrm{b}} \pm \\
1.41\end{array}$ & $\begin{array}{c}6.9^{\mathrm{cd}} \pm \\
1.41\end{array}$ & $\begin{array}{c}5.9^{\mathrm{c}} \pm \\
1.41\end{array}$ \\
\hline & $90: 10$ & $\begin{array}{c}1.0^{\mathrm{b}} \pm \\
0.28 \\
\end{array}$ & $\begin{array}{c}2.5^{\mathrm{c}} \pm \\
1.56 \\
\end{array}$ & $\begin{array}{c}9.9^{c} \pm \\
1.56 \\
\end{array}$ & $\begin{array}{c}12.9^{b c} \pm \\
1.41 \\
\end{array}$ & $\begin{array}{c}7.9^{\mathrm{c}} \pm \\
1.41 \\
\end{array}$ & $\begin{array}{c}5.9^{\mathrm{c}} \pm \\
1.56 \\
\end{array}$ \\
\hline \multirow[t]{3}{*}{ GSM } & 100:0 & $\begin{array}{c}3.9^{\mathrm{b}} \pm \\
1.56\end{array}$ & $\begin{array}{c}2.2^{\mathrm{c}} \pm \\
1.41\end{array}$ & $\begin{array}{l}8.9^{c} \pm \\
0.14\end{array}$ & $\begin{array}{c}12.0^{\mathrm{c}} \pm \\
1.41\end{array}$ & $\begin{array}{c}4.0^{\mathrm{d}} \pm \\
1.41\end{array}$ & $\begin{array}{c}2.5^{\mathrm{d}} \pm \\
0.14\end{array}$ \\
\hline & $95: 5$ & $\begin{array}{l}1.0^{\mathrm{b}} \pm \\
0.57\end{array}$ & $\begin{array}{l}1.8^{\mathrm{c}} \pm \\
1.56\end{array}$ & $\begin{array}{c}13.9^{\mathrm{b}} \pm \\
1.41\end{array}$ & $\begin{array}{c}21.8^{\mathrm{a}} \pm \\
1.41\end{array}$ & $\begin{array}{c}11.9^{\mathrm{b}} \pm \\
1.56\end{array}$ & $\begin{array}{c}19.6^{\mathrm{b}} \pm \\
1.13\end{array}$ \\
\hline & 90:10 & $\begin{array}{c}1.0^{\mathrm{b}} \pm \\
0.85\end{array}$ & $\begin{array}{l}1.8^{\mathrm{c}} \pm \\
1.70\end{array}$ & $\begin{array}{c}21.8^{\mathrm{a}} \pm \\
1.70 \\
\end{array}$ & $\begin{array}{c}24.0^{\mathrm{a}} \pm \\
1.41 \\
\end{array}$ & $\begin{array}{c}24.0^{\mathrm{a}} \pm \\
1.41 \\
\end{array}$ & $\begin{array}{c}22.8^{\mathrm{a}} \pm \\
1.56 \\
\end{array}$ \\
\hline
\end{tabular}

Values are means \pm standard deviations of 3 scores. Means within a column with different superscripts were significantly $(p<0.05)$ different. GNS- grit non-soaking method; GSM- grit soaking method; MFmaize flour; BPF- baobab pulp flour

\section{Conclusion}

Grit soaking operation improved functional and sensory properties of maize flour meant for tuwo production. In addition, inclusion of baobab pulp enhanced the stated properties of maize flour produced by both grit soaking and grit non-soaking methods.

Inclusion of $5 \%$ baobab pulp gave the best stability of tuwo produced by grit soaking method while $10 \%$ baobab pulp inclusion gave the best stability of tuwo produced by grit non-soaking method.

Tuwo stored under refrigerated conditions showed better paste stability compared to those stored at ambient condition. 


\section{References}

1. Nuss, E.T., Tanumihardjo, S.A. (2010), Maize: A Paramount staple crop in the context of global nutrition, Comprehensive Revision in Food Science and Safety, 9(4), pp. 417-436.

2. Shindano, J. (2007), Functional properties of white maize meal stored under tropical conditions, Thesis submitted in fulfillment of the requirements for the degree of doctor $(\mathrm{PhD})$ in Applied Biological Sciences: Chemistry. Faculty of Bioscience Engineering, Ghent University, Belgium, pp. 23-25.

3. Ranum, R., Pena-Rosas, J.P., Garcia-Casal, M.V. (2014 ), Global maize production, utilization, and consumption, Annual New York Academy of Science, 1325, pp. 105-112.

4. Aworh, O.C. (2008), The role of traditional food processing technologies in national development; the West African experience. In: Robertson, G.L., Lupien, J.R. (eds.) Using food science and technology to improve nutrition and promote national development. International Union of Food Science and Technology, pp. 9-10.

5. Bolade, M.K., Adeyemi, I.A., Ogunsua, A.O. (2009), Influence of particle size fractions on the physicochemical properties of maize flour and textural characteristics of a maize-based nonfermented food gel, International Journal of Food Science and Technology, 44, pp. 646655.

6. Bolade, M.K., Adeyemi, I.A. (2014 ), Quality dynamics of maize‘tuwo’ (non-fermented maize-based dumpling) as influenced by steaming of maize grits at different resident time, Journal of Food Science and Technology, 51(11), pp. 3217-3225.

7. Souza, V.F., Nascimento, E.M.G., Ascher, J.L.R. (2011 ), Pasting properties of expanded extrudate and pellets from corn flour and rice flour, Brazilian Journal of FoodTechnology, 14(2), pp. 106-114.

8. Bolade, M.K., Usman, M.A., Rasheed, A.A., Benson, E.L., Salifou, I. (2002), Influence of hydrothermal treatment of maize grains on the quality and acceptability of tuwo masara (traditional maize gel), Food Chemistry, 79, pp. 479-483.

9. De Caluwe, E., Halamova, K., Van Damme, P. (2010), Adansonia digitata - A review of traditional uses, phytochemistry and pharmacology, African Focus, 23(1), pp. 11-51.

10. Chadare, F.J., Linnemann, A.R., Hounhouigan, J.D., Nout, M.J.R., Van Boekel, M.A.J. (2009), Baobab food products: A review on their composition and nutritional value, Critical Review in Food Science and Nutrition, 49(3), pp. 254-274.

11. Fagbohun, A.A., Ikokoh, P.P., Afolayan, M.O., Olajide, O.O., Fatokun, O.A., Akanji, F.T. (2012), Chemical composition and anti-oxidant capacity of the fruit pulp of Adansonia digitata, International Journal of Applied of Chemistry, 8(3), pp. 165-172.

12. Abdalla, A. A., Mohammed, M. A., Mudawi, M. A. (2010), Production and quality assessment of instant baobab drink, Advanced Journal of Food Science and Technology, 2(2), pp. 125-133.

13. Ndabikunze, B.K., Masambu, B.N., Tisekwa, B.P.M., Issa-Zacharia, A. (2011 ), The production of jam from indigenous fruits using baobab (Adansonia digitata $\mathrm{L}$ ) powder as a substitute for commercial pectin, African Journal of Food Science, 5(3), pp. 168-175.

14. Adejuyitan, J.A., Abioye, A., Otunola, E.T., Oyewole, Y. (2012), An evaluation of some properties of baobab fruit powder and ogi mixes, Transnational Journal of Science and Technology, 2(7), pp. 91-102.

15. Kinsella, J.E. (1981), Functional properties of protein: Possible relationship between structure and function in foods, Food Chemistry, 7, pp. 273-288.

16. Akpata, M.I., Miachi, O.E. (2001 ), Proximate composition and selected functional properties of Detarium microcarpum. Plant Foods for Human Nutrition, 56, pp. 297-302.

17. Yadav, R.B., Kumar, N., Yadav, B.S. (2016 ), Characterization of banana, potato and rice starch blends for their physicochemical and pasting properties, Congent Food and Agriculture, 2, pp. 1-12. 
18. Chinma, C.E., Anuonye, J.C., Simon, O.C., Ohiare, R.O., Danbaba, N. (2015 ), Effect of germination on the physicochemical and antioxidant characteristics of rice flour from three rice varieties from Nigeria, Food Chemistry, 185, pp. 454-458.

19. Kaur, M., Oberoi, D.P.S., Sogi, D.S., Gill, B.S. (2011 ), Physicochemical, morphological and pasting properties of acid treated starches from different botanical sources, Journal of Food Science and Technology, 48(4), pp. 460-465.

20. Desalegn, B.B. (2015), effect of soaking and germination on proximate composition, mineral bioavailability and functional properties of chickpea flour, Food and Public Health, 5(4), pp. 108-113.

21. Ocheme, O.B., Oloyede, O.O., Mikailu, E.S. (2010), Effect of Lime Soaking and Cooking (Nixtamalization) on the Proximate, Functional and Some Anti-nutritional Properties of Millet Flour, AU Journal of Technology, 14(2), pp. 131-138

22. Seena, S., Sridhar, K.R. (2005), Physiochemical, functional and cooking properties of under explored legumes, Canavalia of the Southwest coast of India, Food Research International, 38, pp. 803-814.

23. Bolaji, O.T., Awonorin, S.O., Olalusi, P.A., Adepoju, P.A. (2011 ), Evaluation of changes in pasting properties of ogi during storage, Electronic Journal of Environmental, Agricultural and Food Chemistry. 10(1), pp. 1865-1872.

24. Adegunwa, M.O., Sanni, L.O., Maziya-Dixon, B. (2011 ), Effects of fermentation length and varieties on the pasting properties of sour cassava starch, African Journal of Biotechnology, 42, pp. 8428-8433.

25. Apotiola, Z.O. (2013), Effect of soaking period on the ogi powder produced from sorghum, Nigerian Food Journal, 31(1), pp. 103-107.

26. Adebowale, A., Sanni, L.O., Awonorin, S.O. (2005 ), Effect of texture modifiers on the physiochemical and sensory properties of dried fufu, Food Science and Technology International, 11, pp. 373-385.

27. Kajihausa, O.E., Fasasi, R.A., Atolagbe, Y.M. (2014 ), Effect of different soaking time and boiling on the proximate composition and functional properties of sprouted sesame seed flour, Nigerian Food Journal, 32(2), pp. 8-15.

28. Akubor, P.I., Adedeji, O.E. (2016), Effect of $\mathrm{NaCl}$ and $\mathrm{pH}$ on the functional properties of locust bean (Parkia biglobosa) Pulp flour, FUW Science and Technology, 1(2), pp. 344347.

29. Oluwamukomi, M.O., Jolayemi, O.S. (2012 ), Physico-thermal and pasting properties of soy-melon-enriched "gari”" semolina from cassava, Agricultural Engineering International, 14(3), pp. 105-115.

30. Bhupender, S.K., Rajneesh, B., Baljeet, S.Y. (2013), Physicochemical, functional, thermal and pasting properties of starches solated from pearl millet cultivars, International Food Research Journal, 20(4), pp. 1555-156.

31. Correia, P.M.R., Soares, A.M., Brites, C. (2016), Quality characteristics of maize flour and breads, International Journal of Food Engineering, 2(2), pp. 113-118.

32. Zaidul, I.S.M., Yamauchi, H., Kim. S., Hashimoto, N., Noda T. (2007 ), RVA study of mixtures of wheat flour and potato starches with different phosphorus contents, Food Chemistry, 102, pp. 1105-1111.

33. Bolade, M.K. (2009), Effect of flour production methods on the yield, physicochemical properties of maize flour and rheological characteristics of a maize-based non-fermented food dumpling, African Journal of Food Science, 3, pp. 288-298.

34. Senanayeke, S., Gumaratne, A., Ranaweera, K.K.D.S., Bamunuarachchi, A. (2014 ), Effect of hydroxypropylation on functional properties of different cultivars of sweet potato starch in Srilanka, International Journal of Food Science,

DOI: http://dx.doi.org/10.1155/2014/148982. 